\title{
Effects of Korean ginseng (Panax ginseng C.A. Meyer) root extract on egg production performance and egg quality of laying hens
}

\author{
A. Yıldırım ${ }^{1 \#}$, A. Şekeroğlu ${ }^{2}$ H. Eleroğlu ${ }^{3}$, M.I. Şen ${ }^{1} \&$ M. Duman ${ }^{1}$ \\ ${ }^{1}$ Department of Animal Science, Faculty of Agriculture, University of Gaziosmanpaşa, Tokat/Turkey \\ ${ }^{2}$ Department of Animal Production and Technologies, Faculty of Agricultural Sciences and Technologies, \\ University of Niğde, Niğde/Turkey \\ ${ }^{3}$ Aşık Veysel Vocational High School, University of Cumhuriyet, Sivas/Turkey
}

(Received 6 May 2013; Accepted 13 June 2013; First published online 30 July 2013)

\author{
Copyright resides with the authors in terms of the Creative Commons Attribution 2.5 South African Licence. \\ See: http://creativecommons.org/licenses/by/2.5/za \\ Condition of use: The user may copy, distribute, transmit and adapt the work, but must recognise the authors and the \\ South African Journal of Animal Science.
}

\begin{abstract}
This study was conducted to determine the effect of Korean ginseng (Panax ginseng C.A. Meyer) root extract (PGRE) on egg production and egg quality characteristics of hens at the beginning of their laying period (20 weeks old). Four groups of commercial hens (Atak-S; Turkish native hybrid) were fed with diets containing $0 \mathrm{mg}, 50 \mathrm{mg}, 100 \mathrm{mg}$ and $150 \mathrm{mg}$ PGRE/kg. Experimental results indicated that dietary PGRE had no effect on feed intake, feed efficiency, egg mass (EM) or egg production parameters. Over 12 weeks, hen-day egg production (HDP) of the groups was 73.5\%, 74.8\%, 69.2\% and 79.0\%, respectively. The effect of different levels of PGRE on egg weight, shape index (SI), specific gravity, shell thickness, Haugh Unit (HU), yolk index (YI) and albumen index (AI) was not statistically significant during the entire experiment. Egg yolk colour was conspicuously lower in the $100 \mathrm{mg}$ and $150 \mathrm{mg}$ PGRE/kg groups than in the control. The $L^{*}, a^{*}$ and $b^{*}$, hue $(H)$ and chroma $\left(C^{*}\right)$ values for eggshell colour were not significantly different among the groups, except for the colour difference $\left(\Delta \mathrm{E}^{*},\left(\mathrm{~L}^{2}+\mathrm{a}^{2}+\mathrm{b}^{2}\right)^{1 / 2}\right)$, where values in PGRE groups were higher than in the control group. The trolox equivalent antioxidant capacity (TEAC), ferric reducing antioxidant power (FRAP) and total phenolics concentration of PGRE were $598 \pm 1.841 \mathrm{mmol}$ trolox/kg, $15.45 \pm 0.457 \mathrm{mmol}$ TEAC/kg and $1.02 \pm 0.03 \mathrm{~g}$ gallic acid equivalents (GAE) $/ \mathrm{kg}$, respectively. Serum glucose, cholesterol and triglyceride concentration were similar in the PGRE supplemented groups and the control. In conclusion, the dietary supplementation with PGRE did not affect the productivity performance traits and egg quality of hens at the beginning of the laying period.
\end{abstract}

Keywords: Herb extract, egg yield, egg traits, egg shell colour, biochemical parameters, antioxidant activity

"Corresponding author: arda.yildirim@gop.edu.tr

\section{Introduction}

The ban on antibiotic use to enhance growth and feed efficiency and reduce mortality in poultry constitutes a major challenge to the egg industry because healthy flocks must be maintained for effective production. Thus alternative feeding strategies have been incorporated into laying hen diets to improve gut health of the birds, enhance productive performance and improve egg quality (Olobatoke \& Mulugeta, 2011). Recent studies concentrated on aromatic plants, their extracts and essential oils. This has increased the interest in those herbs that possess characteristics such as antioxidant, anti-stress, lowering cholesterol, and cancer prevention properties in their phenolic compounds (Yıldırım \& Erener, 2011). Natural feed additives of plant origin are generally believed to be safer, healthier and less subject to hazards for human beings and animals than antibiotics. One of the mechanisms underlying the health-related benefits may be associated with their antioxidant properties (Kim et al., 2011). Many herbs and plant extracts possess antimicrobial activities and antioxidant properties that make them useful as natural animal feed additives (Faixova \& Faix, 2008). These extracts present a mechanism of action based on the alteration of the intestinal microbiota, 
increased enzyme secretion, improved immune response, morpho-histological maintenance of the gastrointestinal tract and antioxidant activity (Brugalli, 2003; Fascina et al., 2012). Several studies have demonstrated their in vitro effect against pathogens because of antimicrobial, antifungal and anthelmintic activities, in addition to powerful antioxidant effects (Kamel, 2000; Petrolli et al., 2012).

Panax ginseng C.A. Meyer (Araliaceae), also called Asian ginseng, is one of the most renowned herbal plants worldwide, but particularly in Asian countries, and has been used for thousands of years to maintain homeostasis of the body and enhance vital energy (Attele et al., 1999; Choi, 2008; Yıldırım \& Erener, 2011). It is considered an adaptogenic agent that helps to enhance physical performance, promote vitality and stimulate metabolic function. It has previously been documented that bioactive components such as saponins (ginsenosides), antioxidants, peptides, polysaccharides, alkaloids, lignans and polyacetylenes are present in P. ginseng (Sticher, 1998; Palazon et al., 2003; Lu et al., 2009). Among these, the saponins (ginsenosides) are considered the principal bioactive ingredients (Palazon et al., 2003) and are believed to possess anti-fatigue and hepatoprotective physiological properties (Wu \& Zhong, 1999), and improve cardiovascular system dysfunction (Kang et al., 1995). Likewise, numerous studies have demonstrated the pharmaceutical effects of $P$. ginseng on physical, chemical and biological stress (Takahashi et al., 1992; Shim et al., 2010), systemic immune function (Spelman et al., 2006) and glucose metabolism (Lim et al., 2009). The presence of ginsenoside in the $P$. ginseng complex contributed to the improvement in the parameters evaluated by its antimicrobial and antioxidant potential, as confirmed by Takahashi et al. (1992); Kim et al. (2008), Zhang et al. (2008) and Lim et al. (2009).

Because of these benefits, ginseng extracts may exert positive effects on performance and egg quality in laying hens. However, Ao et al. (2011) reported that dietary supplementation with fermented red ginseng extract did not influence performance and egg quality in ISA brown layers at 35 weeks of age. To our knowledge, there is no evidence that dietary supplementation with Korean ginseng root extract (PGRE) would have beneficial effects on productivity performance and egg quality of hens at the beginning of lay. Therefore, the aim of the present study was to determine the effects of supplementing graded levels of a commercial PGRE on egg production performance, egg quality and some serum biochemical traits in laying hens at 20 weeks of age.

\section{Materials and Methods}

Eighty commercial Atak-S brown layers at the age of 20 weeks were randomly allocated to one of four treatments with four replicates of five hens per treatment in a completely randomized design. The five birds per replicate were kept in a wire cage $\left(450 \mathrm{~cm}^{2}\right.$ per bird) in a windowed poultry house at a light regimen of $16 \mathrm{~h}$ light and $8 \mathrm{~h}$ dark.

The treatments were a basal diet as control and three levels of supplementation, 50, 100 and 150 $\mathrm{mg} / \mathrm{kg}$ diet of a commercial PGRE (Batch No: GRE-110312, Dried, 100\% Natural), supplied by Changsha Herbway Biotech Co. Ltd. (China). The PGRE contained $80.4 \%$ ginsenosides, as determined by Changsha Herbway Biotech UV using spectrophotomeric analysis. Feed and water were supplied ad libitum. The experimental diets were isonitrogenous and isoenergetic and were formulated to meet or slightly exceed the nutrient requirement of laying hens according to the NRC (1994). The ingredients and calculated nutrient level of the basal diet are shown in Table 1.

This study was approved by the Animal Experimentation Ethics Committee (Process no. 306/2011 HADYEK- 038) of Gaziosmanpaşa University. Animals in this experiment were cared for under the guidelines stated in the Guide for the Care and Use of Atak-S brown hybrid laying hens in the Poultry Research Institute, Ankara, Turkey. Prior to the experiment, the birds were given a two-week adaptation period and the trial lasted 12 weeks.

Three portable temperature and relative humidity loggers (HOBO U12-012 T/RH logger, temperature measuring range between $-20{ }^{\circ} \mathrm{C}$ and $70{ }^{\circ} \mathrm{C}$ with $\pm 0.35{ }^{\circ} \mathrm{C}$ accuracy; relative humidity range of $5 \%-95 \%$ with $\pm 2.5 \%$ accuracy) were used to monitor indoor temperature and relative humidity at animal level. Data were recorded every $60 \mathrm{~min}$ and downloaded weekly throughout the experiment. The average temperature, relative humidity and light intensity of the entire experimental period were $15.74 \pm 0.129^{\circ} \mathrm{C}, 48.15 \pm 6.410 \%$ and $14.76 \pm 3.828 \%$ lux, respectively. 
Table 1 Composition and nutrient content of basal diet $(\mathrm{g} / \mathrm{kg})$

\begin{tabular}{lcclcc}
\hline & Ingredients & & \multicolumn{3}{c}{ Calculated nutrients composition } \\
\hline & $18-20$ weeks & $20-32$ weeks & ME (MJ/kg) & 18 - 20 weeks & 20 - 32 weeks \\
\hline Maize & 301 & 269 & M. & 880 & 11.72 \\
Wheat & 254 & 255 & Dry matter & 890 \\
Soybean meal (47\% CP) & 64 & 92 & Crude protein (CP) & 160 & 172 \\
Sunflower meal (27\% CP) & 140 & 0 & Crude fat & 30.5 & 50.0 \\
Barley & 100 & 30 & Lysine & 7.2 & 8.0 \\
Sunflower meal (36\% CP) & 0 & 80 & Methionine & 3.5 & 4.5 \\
Full-fat soybean & 58 & 100 & Methionine+cystine & 6.4 & 7.6 \\
Soybean oil & 0 & 24 & Tryptophan & 2.0 & 1.9 \\
Sodium bicarbonate & 2 & 1 & Crude fibre & 60 & 42.5 \\
Dicalcium phosphate & 12 & 14 & Calcium & 10 & 36.0 \\
Marble powder & 17 & 83 & Available phosphorus & 3.6 & 4.0 \\
Salt & 2 & 2 & Sodium & 1.6 & 1.6 \\
Vitamin-mineral premix* & 50 & 50 & & &
\end{tabular}

* Each kg of vitamin-mineral premix contained: 4800000 IU vitamin $\mathrm{A} ; 1200000$ IU vitamin $\mathrm{D}_{3}$; 12000000 IU vitamin E; $1600 \mathrm{mg}$ vitamin $\mathrm{K}_{3} ; 1200 \mathrm{mg}$ vitamin $\mathrm{B}_{1} ; 2400 \mathrm{mg}$ vitamin $\mathrm{B}_{2} ; 12000 \mathrm{mg}$ vitamin $\mathrm{B}_{3} ; 4000 \mathrm{mg}$ vitamin $\mathrm{B}_{5} ; 2000$ $\mathrm{mg}$ vitamin $\mathrm{B}_{6}$; $20000 \mathrm{mg}$ vitamin $\mathrm{C}$; $6 \mathrm{mg}$ vitamin $\mathrm{B}_{12}$; biotin; $400 \mathrm{mg}$ folic acid; $120000 \mathrm{mg}$ choline; $2000 \mathrm{mg} \mathrm{Cu}$; 24000 mg Fe; 32000 mg Mn; 60 mg Se; 24000 mg Zn; 200 mg Co; 800 mg I.

Hens were weighed individually at the beginning and end of the experiment. Feed consumption was recorded weekly and calculated as g per hen per day. Viability was observed visually and recorded daily. Feed efficiency was calculated as g feed per g egg.

The first eggs were laid within 23 weeks of age in all the groups. Eggs from each replicate were collected twice a day (09:00 - 11:00 and 14:00 - 16:00) and weighed with an electronic balance at the same time every day to calculate hen-day egg production (HDP), hen-house production (HHP), egg weight and egg mass (EM) from 20 weeks to 32 weeks of age. In addition, age at point-of-lay, first egg weight, age (day) at 10\%, 20\%, 30\% and 50\% egg production were recorded. Thirty two eggs were randomly collected from each experimental group on the last day of every two-week period to assess egg quality. Immediately after sampling, eggs were assayed for quality. An average of three measurements (3 times) taken at the equator, blunt edge and pointed edge of the egg were recorded for lightness $\left(\mathrm{L}^{*}\right)$, redness $\left(\mathrm{a}^{*}\right)$, and yellowness ( $b^{*}$ ) of the eggshell, using a Minolta CR400 chromameter (Konica Minolta Sensing Inc., Osaka, Japan). The psychometric colour terms such as, $\mathrm{H}, \mathrm{C}^{*}$ and the total colour difference over time $\left(\Delta \mathrm{E}^{*}\right)$ were used in order to evaluate colour changes of the eggshell. The egg quality traits included specific gravity, eggshell breaking strength, shell thickness, yolk colour and albumen $\mathrm{pH}$. All eggs were weighed individually. Egg specific gravities were determined using graded salt solutions ranging from 1.069 to 1.099 with gradations of 0.003, as described by Hamilton (1982). After that, shell breaking strength was measured using a shell strength device with a spiral pressure system (Fujihara, Saitama, Japan). Subsequently, the egg was broken on a glass plate, and after 5 min albumen and yolk heights were measured using a tripod micrometer, as well as the long and short diameters of the albumen and diameter of the yolk using a digital calliper with a sensitivity of $0.001 \mathrm{~mm}$. The formulas of the egg quality traits are presented in Table 2. Shell thickness was calculated as the average of three measurements; taken at the equator, blunt edge and pointed edge of the egg without membrane using a calliper. The yolk colour was determined with a DSM (2013) yolk colour fan (DSM Nutritional Products Ltd., Basel, Switzerland), which ranges from a pale yellow at score 1 to a dark orange at score 15, according to the CIE standard colorimetric system.

At the age of 32 weeks, about $5 \mathrm{~mL}$ blood of 32 hens, representative of all treatments, were collected by venipuncture of the wing vein (Vena cutanea ulnaris) in a glass tube (16 mm x $100 \mathrm{~mm})$. The tube was kept on ice and transferred to the laboratory. Blood samples were left to stand at room temperature for clotting, and then the serum was obtained by centrifugation at $3000 \mathrm{x} g$ for $5 \mathrm{~min}$. The supernatant was 
collected in a $1.5 \mathrm{~mL}$ Eppendorf tube and stored at $-20{ }^{\circ} \mathrm{C}$ for biochemical assays. The concentrations of serum glucose, cholesterol and triglyceride were measured, using commercial kits (Cat. No. GLU0102, TC0102 and TG0102) on an auto-analyser (Mindray BS series analysers, Hamburg, Germany).

Table 2 Formulas for measurement of egg quality traits

\begin{tabular}{|c|c|c|}
\hline Criteria & Abbrev. & Equation \\
\hline${ }^{1}$ Hen-day production, \% & HDP & (Number egg produced / number live hens) x 100 \\
\hline${ }^{1}$ Hen-house production, \% & HHP & (Number egg produced / number live hens in initial experiment) x 100 \\
\hline${ }^{2}$ Shape index, \% & SI & (Egg width/egg length ) x 100 \\
\hline${ }^{2}$ Yolk index, \% & YI & (Yolk height/yolk diameter) x 100 \\
\hline${ }^{2}$ Albumen index, \% & AI & $\begin{array}{l}\text { [Albumen height/(long diameter of albumen+short diameter of albumen } \\
/ 2) \times 100 \text { ] }\end{array}$ \\
\hline${ }^{3}$ Egg surface area $\left(\mathrm{cm}^{2}\right)$ & ES & 3.9782 x egg weight ${ }^{0.70}$ \\
\hline${ }^{4}$ Shell weight (g) & SW & (2.0341 x egg weight)-[(2.1014 x egg weight)/specific gravity] \\
\hline${ }^{5}$ Haugh unit (score) & HU & $100 \log$ (albumen height+7.57-1.7 $\mathrm{W}^{0.37}$ ) \\
\hline${ }^{6}$ Egg mass (g/hen/day) & EM & (weekly egg number in replicate $\mathrm{x}$ average egg weight)/100 \\
\hline Hue angle & $\mathrm{H}$ & $\tan -1 \mathrm{~b} * / \mathrm{a}^{*}$ \\
\hline Chroma & $\mathrm{C}^{*}$ & $\sqrt{ }\left(a^{*^{2}}+b^{*^{2}}\right)$ \\
\hline Colour difference & $\Delta \mathrm{E}^{*}$ & $\left(\mathrm{~L}^{2}+\mathrm{a}^{2}+\mathrm{b}^{2}\right)^{1 / 2}$ \\
\hline
\end{tabular}

Total antioxidant activity was measured using Oyaizu's (1986) ferric reducing antioxidant power (FRAP) assay method. The antioxidant capacity assay was carried out with a Spectronic Genesys 5 spectrophotometer by the improved $\mathrm{ABTS}^{\circ+}$ method, as described by Re et al. (1999). A total phenolic constituent of PGRE was performed, employing the literature methods involving Folin-Ciocalteu reagent and gallic acid as standard (Slinkard \& Singleton, 1977).

Data in the tables are presented as arithmetic means and standard error of means (SEM). The data were analysed by SPSS 16.0 software for Windows (Inc. Chicago, IL. USA). The differences between groups were determined by one-way ANOVA test. Duncan's multiple-range tests were performed according to the following model:

$$
Y_{i j}=\mu+T_{i}+e_{i j}
$$

where $Y$ denotes the dependent variable; $\mu$ denotes the mean; $T$ is the effect of treatment; and $e$ is the random residual error term. All values were presented as means and standard error mean and significance levels were set at $P<0.05$.

\section{Results and Discussion}

The total phenolic content, TEAC value and FRAP value of PGRE (dry matter) were $1.02 \pm 0.03 \mathrm{~g}$ gallic acid equivalents (GAE) $/ \mathrm{kg}, 598 \pm 1.841 \mathrm{mmol}$ trolox $/ \mathrm{kg}$ and $15.45 \pm 0.457 \mathrm{mmol} \mathrm{TEAC} / \mathrm{kg}$, respectively. These values are higher than those reported by Hu \& Kitts (2001) and Saumya \& Mahaboob Basha (2011). Oh et al. (2010) claimed that the antioxidant capacity of ginseng extract may have the potential to be used as an effective dietary antioxidant to prevent oxidative stress-related diseases. The results in the current study demonstrate the antioxidant potential of PGRE, evidenced by its free radical scavenging and ferric reducing abilities. This supports the use of the plant in traditional medicine. Moreover, when consumed as the plant extract, PGRE may contribute to the total intake of dietary antioxidants.

The performance and egg productivity traits of the laying hens fed diets supplemented with PGRE are shown in Tables 3 and 4. Supplementation of diets with PGRE had no significant effects on body weight, body weight gain, viability, feed intake (Figure 1), total feed intake and feed efficiency when compared with 
the control $(P>0.05)$. These results are consistent with the findings of Ao et al. (2011), who reported no positive effects on egg production, feed intake and egg weight in laying hens fed different levels of fermented red ginseng extract. No differences were observed in laying hens fed the various experimental diets in age at point-of-lay, age at 10\%, 20\%,30\% and 50\% egg production, first egg weight, egg weight and egg weight according to oviposition time, EM, HHP and HDP (Table 4). The lower egg production and EM between 0 and 4 weeks might be because that all hens unexpectedly laid during weeks 22 and 23. In general, all parameters were similar in the graded PGRE supplemented group compared with the control group, except that egg production of the 50 and $150 \mathrm{mg}$ PGRE/kg groups was higher than the control, though did not reach statistical significance.

Viability was higher in laying hens fed diets supplemented with the PGRE than in those fed the control diet. This suggests that up to $150 \mathrm{mg}$ PGRE/kg in a diet can be used as an ingredient without any adverse effect on production performance in laying hens or at $11.7 \mathrm{mg} / \mathrm{bird} / \mathrm{day}$ or $100 \mathrm{mg} / \mathrm{kg}$ of body weight.

Table 3 Body weight, feed intake, feed efficiency of laying hens fed on diets supplemented with PGRE

\begin{tabular}{|c|c|c|c|c|c|c|}
\hline \multirow{2}{*}{ Parameters } & \multicolumn{4}{|c|}{ PGRE $^{1}$ in diet $(\mathrm{mg} / \mathrm{kg})$} & \multirow{2}{*}{$\mathrm{SEM}^{2}$} & \multirow{2}{*}{$P$ value } \\
\hline & 0 & 50 & 100 & 150 & & \\
\hline Initial body weight (g) & 1312 & 1316 & 1316 & 1315 & 8.49 & 0.999 \\
\hline Final body weight (g) & 1793 & 1777 & 1744 & 1822 & 12.92 & 0.209 \\
\hline Body weight gain (g) & 476.8 & 461.8 & 424.8 & 506.8 & 17.42 & 0.448 \\
\hline Viability (\%) & 95.0 & 100.0 & 85.0 & 100.0 & 3.87 & 0.517 \\
\hline \multicolumn{7}{|l|}{ Feed intake (g/hen/day) } \\
\hline 0 - 4 weeks & 86.2 & 93.1 & 81.0 & 90.7 & 2.43 & 0.330 \\
\hline 4 - 8 weeks & 126.2 & 124.7 & 124.7 & 128.6 & 1.77 & 0.876 \\
\hline 8 - 12 weeks & 140.3 & 132.6 & 141.6 & 139.7 & 2.49 & 0.624 \\
\hline Overall & 117.2 & 116.8 & 113.7 & 119.6 & 1.48 & 0.606 \\
\hline \multicolumn{7}{|c|}{ Total feed intake (g/hen/day) } \\
\hline 0 - 12 weeks & 9843 & 9811 & 9547 & 10049 & 124.38 & 0.606 \\
\hline \multicolumn{7}{|c|}{ Feed efficiency (g feed/g egg) } \\
\hline $0-4$ weeks & 16.15 & 13.63 & 9.94 & 15.79 & 2.22 & 0.783 \\
\hline 4 - weeks & 2.90 & 2.80 & 3.07 & 2.67 & 0.11 & 0.703 \\
\hline 8 - 12 weeks & 2.60 & 2.48 & 2.74 & 2.55 & 0.06 & 0.567 \\
\hline Overall & 3.47 & 3.41 & 3.63 & 3.30 & 0.074 & 0.487 \\
\hline \multicolumn{7}{|c|}{ Feed efficiency (g feed/dozen egg) } \\
\hline 0 - 4 weeks & 4.63 & 3.93 & 2.77 & 4.41 & 0.62 & 0.759 \\
\hline 4 - 8 weeks & 2.00 & 1.89 & 2.02 & 1.82 & 0.07 & 0.789 \\
\hline 8 - 12 weeks & 1.87 & 1.78 & 1.91 & 1.83 & 0.04 & 0.771 \\
\hline Overall & 2.44 & 2.36 & 2.45 & 2.29 & 0.05 & 0.690 \\
\hline
\end{tabular}

${ }^{\mathrm{T}}$ PGRE, Korean ginseng root extract; ${ }^{2}$ Mean of standard error; $P>0.05$.

The parameters used to evaluate external and internal egg quality are shown in Tables 5 and 6 . The results demonstrate that levels of PGRE did not affect overall SI, specific gravity, shell breaking strength, eggshell thickness, albumen $\mathrm{pH}, \mathrm{AI}, \mathrm{YI}, \mathrm{ES}, \mathrm{SW}$ and $\mathrm{HU}(P>0.05)$, except for yolk colour, which was paler when $100 \mathrm{mg}$ and $150 \mathrm{mg}$ PGRE/kg were included in the diets $(P<0.05)$. Moreover, this difference was maintained in the fifth, seventh and the eleventh weeks in the present study. Egg weight and eggshell quality characteristics vary according to oviposition time. These results are consistent with those of several studies 
that indicated that eggs laid early in the morning are heavier than eggs laid in the day (Ledvinka et al., 2002; Tůmová \& Ebeid, 2005; Tůmová et al., 2007). However, heavier eggs were laid in the afternoon than in the morning, though in all groups morning HDP values were higher than in the afternoon.

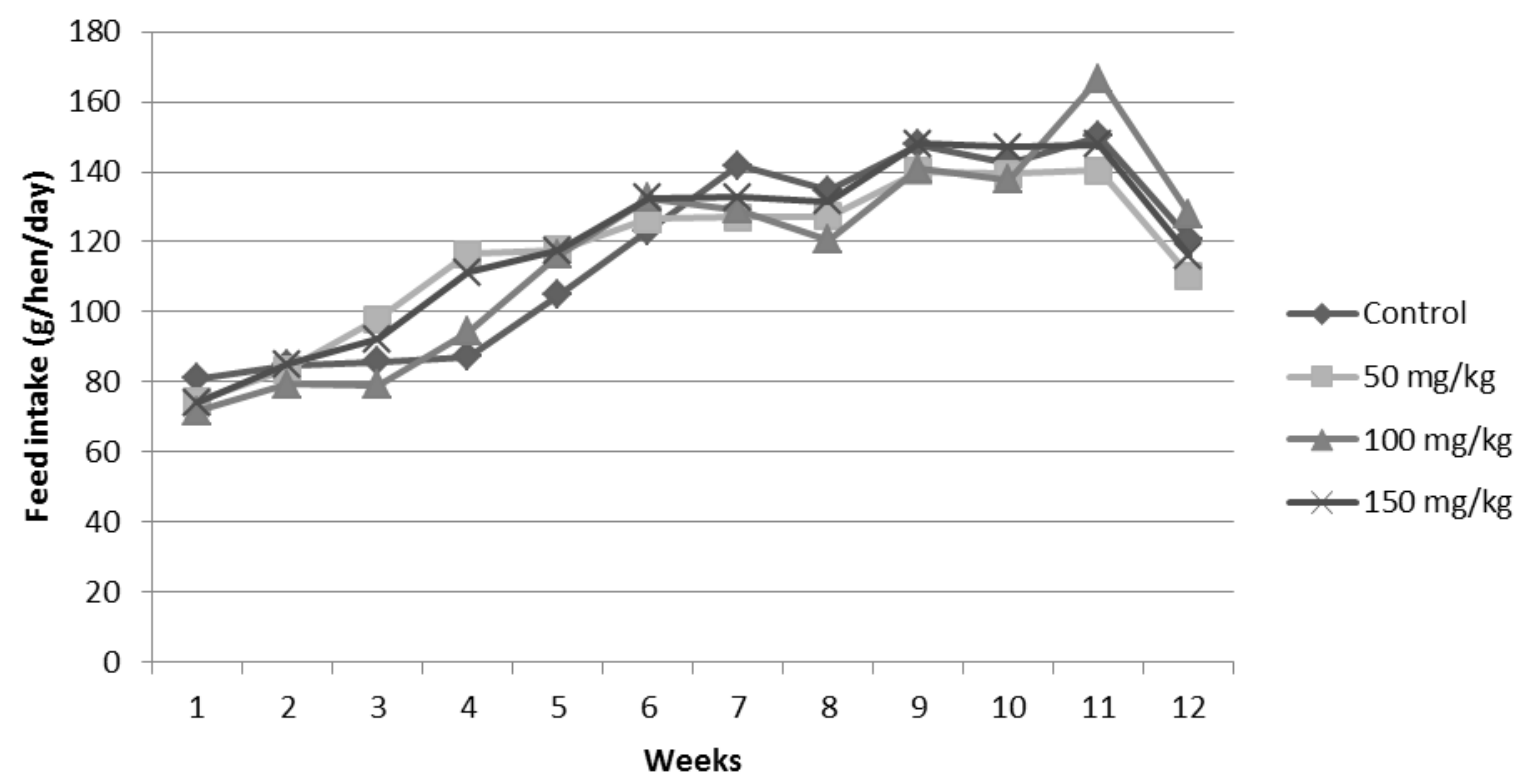

Figure 1 Daily feed intake values on a weekly basis.

It is well documented that yolk colour is influenced mainly by components of the hen's diet (Colin et al., 2004), such as natural pigments. The yolk pigment, xanthophylls, depends on fat-soluble pigments in the diet (Leeson \& Summers, 1997; Lokaewmanee et al., 2011). The paler yolk at inclusions of $100 \mathrm{mg}$ and 150 mg PGRE/kg suggests that xanthophylls interacted with ginsenosides of PGRE. Pale yolks can results from any factor that inhibits liver function, subsequent lipid metabolism and deposition of pigment in the yolk (Chukwuka et al., 2011).

Contrary to expectations, significant differences were found in the ninth week of the present study in specific gravity, eggshell thickness, albumen $\mathrm{pH}$, AI and SW between treatments. The cause is not obvious and difficult to explain. Specific gravity data in the current study correspond with those of Lim et al. (2003), who recorded a medium specific gravity ranging from 1.085 to 1.095 in 21-week-old ISA brown laying hens.

Albumen quality is an important indicator of egg freshness, and is significant for the egg processing industry (Jin et al., 2011). Silversides \& Villeneuve (1994) suggested that $\mathrm{pH}$ is a useful means of describing changes in albumen quality over time during storage. However, albumen $\mathrm{pH}$ is not affected by PGRE groups and can be used to measure egg freshness. Overall albumen $\mathrm{pH}$ ranged from 8.64 to 8.72, which is in agreement with previous data, such as 8.72 for Atak laying hens (Sekeroğlu et al., 2010) and 8.29 to 8.39 for 30-wk-old Dekalb white laying hens (Olobatoke \& Mulugeta, 2011).

Hens fed the diets supplemented with PGRE had numerically the highest HU scores, but lowest SW values compared with the control $(P>0.05)$. Between 20 and 32 weeks of age, egg thickness and egg breaking strength parameters were similar among groups. The results agree with those reported by Ao et al. (2011), who found no significant effect of dietary fermented red ginseng extract supplemented at 1 to $4 \mathrm{~g} / \mathrm{kg}$ on HU, eggshell thickness and egg breaking strength parameters in ISA brown laying hens. However, it is in disagreement with similar scores found for egg yolk. Conversely, Jang et al. (2007) reported that fermented wild ginseng culture by-product increased egg production which may be attributed to the improvement in health status of birds fed supplemented diets. This inconsistency might be due to the use of different ginseng sources, and different methods of preparation of the ginseng products and strains used in the experiments. In addition, the level of PGRE supplementation might not have been high enough to cause an improvement in egg productivity performance. 
Table 4 Effects of dietary PGRE levels on egg productivity performance traits of laying hens

\begin{tabular}{|c|c|c|c|c|c|c|}
\hline \multirow[b]{2}{*}{ Parameters } & \multicolumn{4}{|c|}{ PGRE $^{1}$ in diet (mg/kg) } & \multirow[b]{2}{*}{$\mathrm{SEM}^{2}$} & \multirow[b]{2}{*}{$P$ value } \\
\hline & 0 & 50 & 100 & 150 & & \\
\hline Age at point-of-lay (days) & 160.8 & 159.5 & 157.0 & 160.0 & 0.70 & 0.270 \\
\hline \multicolumn{7}{|l|}{ Egg production age (days) } \\
\hline $10 \%$ & 159.5 & 158.5 & 157.0 & 157.0 & 0.68 & 0.597 \\
\hline $20 \%$ & 160.5 & 160.5 & 157.0 & 158.0 & 0.91 & 0.501 \\
\hline $30 \%$ & 162.0 & 161.0 & 159.5 & 159.0 & 0.84 & 0.684 \\
\hline $50 \%$ & 166.5 & 165.5 & 168.5 & 165.5 & 0.82 & 0.640 \\
\hline First egg weight (g) & 46.7 & 47.2 & 45.9 & 46.8 & 0.84 & 0.947 \\
\hline \multicolumn{7}{|l|}{ Egg weight (g) } \\
\hline 0 - 4 weeks & 48.3 & 49.4 & 49.0 & 50.0 & 0.47 & 0.675 \\
\hline 4 - 8 weeks & 57.8 & 56.3 & 54.6 & 56.6 & 0.55 & 0.253 \\
\hline 8 - 12 weeks & 60.5 & 59.9 & 58.2 & 59.7 & 0.38 & 0.178 \\
\hline Overall & 58.8 & 57.7 & 56.1 & 57.8 & 0.47 & 0.266 \\
\hline \multicolumn{7}{|l|}{ Egg mass (g/hen/day) } \\
\hline 0 - 4 weeks & 9.8 & 11.9 & 11.7 & 15.5 & 1.86 & 0.784 \\
\hline 4 - 8 weeks & 45.2 & 44.9 & 41.3 & 48.1 & 1.55 & 0.533 \\
\hline 8 - 12 weeks & 54.0 & 53.7 & 52.0 & 54.7 & 0.56 & 0.377 \\
\hline Overall & 43.1 & 43.2 & 38.8 & 45.5 & 1.07 & 0.149 \\
\hline \multicolumn{7}{|l|}{ Oviposition time } \\
\hline Morning egg weight (g) & 59.6 & 58.3 & 56.5 & 58.2 & 0.49 & 0.161 \\
\hline Afternoon egg weight (g) & 55.4 & 55.3 & 54.6 & 56.1 & 0.57 & 0.855 \\
\hline \multicolumn{7}{|l|}{$\begin{array}{l}\text { Hen-house egg production (\%) } \\
\text { ( })\end{array}$} \\
\hline 0 - 4 weeks & 20.0 & 24.1 & 22.7 & 30.9 & 3.65 & 0.788 \\
\hline 4 - 8 weeks & 78.0 & 79.8 & 67.0 & 85.2 & 3.25 & 0.259 \\
\hline 8 - 12 weeks & 85.4 & 89.6 & 78.8 & 91.8 & 3.29 & 0.560 \\
\hline Overall & 71.6 & 74.8 & 64.6 & 79.0 & 2.63 & 0.277 \\
\hline \multicolumn{7}{|l|}{ Hen-day egg production (\%) } \\
\hline 0 - 4 weeks & 20.0 & 24.1 & 23.6 & 30.9 & 3.67 & 0.801 \\
\hline 4 - 8 weeks & 78.0 & 79.7 & 75.6 & 85.2 & 2.60 & 0.655 \\
\hline 8 - 12 weeks & 89.3 & 89.6 & 89.3 & 91.8 & 1.05 & 0.839 \\
\hline Overall & 73.5 & 74.8 & 69.2 & 79.0 & 1.89 & 0.356 \\
\hline Morning hen-day egg yield (\%) & 58.4 & 59.4 & 53.3 & 60.2 & 2.18 & 0.728 \\
\hline Afternoon hen-day egg yield (\%) & 15.1 & 15.4 & 15.7 & 18.9 & 1.20 & 0.701 \\
\hline
\end{tabular}

${ }^{1}$ PGRE: Korean ginseng root extract; ${ }^{2}$ Mean of standard error; $P>0.05$.

The results of measurements of the eggshell colour, $\mathrm{L}^{*}, \mathrm{a}^{*}, \mathrm{~b}^{*}, \mathrm{H}, \mathrm{C}^{*}$ and $\Delta \mathrm{E}^{*}$, are presented in Table 7. Overall $\mathrm{L}^{*}, \mathrm{a}^{*}, \mathrm{~b}^{*}, \mathrm{H}$ and $\mathrm{C}^{*}$ did not differ among treatments. However, in the third and eleventh weeks, there were significant differences in the $\mathrm{L}^{*}, \mathrm{a}^{*}, \mathrm{H}$ and $\Delta \mathrm{E}^{*}$ values among groups. Adding PGRE to diet increased $(P<0.01)$ the lightness $\left(\mathrm{L}^{*}\right)$ of the eggshell and reduced redness $\left(\mathrm{a}^{*}\right)$ compared with the control. These effects were reflected in the same way in the other parameters $\left(\mathrm{H}, \mathrm{C}^{*}\right.$ and $\left.\Delta \mathrm{E}^{*}\right)$, though this was not observed in the fifth, seventh and ninth weeks, except for $\Delta \mathrm{E}^{*}$. However, it was observed that the lightness $\left(\mathrm{L}^{*}\right)$ values of the eggshells decreased, and redness $\left(\mathrm{a}^{*}\right)$ values increased gradually until the period of peak efficiency, that is, the colour of the eggshell became darker as the laying hens became older. This is 
Table 5 Effects of dietary PGRE levels on means of external egg quality characteristics

\begin{tabular}{|c|c|c|c|c|c|c|c|}
\hline \multirow{2}{*}{ Parameters } & \multirow{2}{*}{$\begin{array}{l}\mathrm{PGRE}^{1} \\
(\mathrm{mg} / \mathrm{kg})\end{array}$} & \multicolumn{6}{|c|}{ Weeks } \\
\hline & & 3 & 5 & 7 & 9 & 11 & Overall \\
\hline \multirow{4}{*}{ Shape index } & 0 & 74.58 & 75.94 & 77.04 & 77.35 & 76.13 & 76.47 \\
\hline & 50 & 77.27 & 75.28 & 75.99 & 76.79 & 76.36 & 76.17 \\
\hline & 100 & 74.15 & 76.66 & 78.73 & 76.26 & 78.66 & 77.36 \\
\hline & 150 & 74.73 & 76.28 & 76.64 & 76.51 & 77.83 & 76.58 \\
\hline $\mathrm{SEM}^{2}$ & & 0.57 & 0.37 & 0.46 & 0.31 & 0.51 & 0.20 \\
\hline$P$ value & & 0.315 & 0.639 & 0.177 & 0.680 & 0.260 & 0.217 \\
\hline \multirow{4}{*}{ Specific gravity $\left(\mathrm{g} / \mathrm{cm}^{3}\right)$} & 0 & 1.090 & 1.088 & 1.090 & $1.090^{\mathrm{a}}$ & 1.092 & 1.09 \\
\hline & 50 & 1.090 & 1.089 & 1.090 & $1.087^{\mathrm{b}}$ & 1.092 & 1.09 \\
\hline & 100 & 1.090 & 1.090 & 1.088 & $1.092^{\mathrm{a}}$ & 1.090 & 1.09 \\
\hline & 150 & 1.090 & 1.089 & 1.088 & $1.089^{\mathrm{ab}}$ & 1.090 & 1.09 \\
\hline $\mathrm{SEM}^{2}$ & & 0.00 & 0.00 & 0.00 & 0.00 & 0.00 & 0.00 \\
\hline$P$ value & & 1.000 & 0.920 & 0.371 & $0.026^{*}$ & 0.176 & 0.623 \\
\hline \multirow{4}{*}{$\begin{array}{l}\text { Shell breaking strength } \\
\left(\mathrm{kg} / \mathrm{cm}^{2}\right)\end{array}$} & 0 & 2.31 & 1.40 & 2.17 & 2.74 & 2.59 & 2.21 \\
\hline & 50 & 0.98 & 1.72 & 2.04 & 2.28 & 2.95 & 2.17 \\
\hline & 100 & 2.09 & 1.98 & 1.79 & 2.72 & 2.19 & 2.17 \\
\hline & 150 & 1.82 & 1.65 & 2.07 & 2.37 & 2.77 & 2.17 \\
\hline SEM $^{2}$ & & 0.19 & 0.13 & 0.16 & 0.13 & 0.11 & 0.07 \\
\hline$P$ value & & 0.122 & 0.528 & 0.866 & 0.527 & 0.094 & 0.996 \\
\hline \multirow{4}{*}{ Egg shell thickness $(\mu \mathrm{m})$} & 0 & 346.7 & 323.3 & 339.2 & $372.3^{\mathrm{a}}$ & 359.6 & 347.8 \\
\hline & 50 & 336.7 & 313.3 & 315.4 & $339.2^{\mathrm{b}}$ & 361.7 & 332.6 \\
\hline & 100 & 321.7 & 317.6 & 327.9 & $369.2^{\mathrm{a}}$ & 345.7 & 339.5 \\
\hline & 150 & 340.0 & 332.9 & 332.5 & $358.3^{\mathrm{a}}$ & 359.6 & 345.2 \\
\hline $\mathrm{SEM}^{2}$ & & 4.46 & 4.49 & 3.72 & 3.51 & 3.33 & 2.24 \\
\hline$P$ value & & 0.367 & 0.455 & 0.138 & $0.001^{* *}$ & 0.344 & 0.078 \\
\hline \multirow{4}{*}{ Surface area $\left(\mathrm{cm}^{2}\right)$} & 0 & 60.52 & 64.06 & 68.78 & 70.41 & 69.69 & 67.70 \\
\hline & 50 & 61.45 & 63.49 & 67.05 & 68.55 & 69.06 & 66.71 \\
\hline & 100 & 59.18 & 63.15 & 66.33 & 69.05 & 69.74 & 66.61 \\
\hline & 150 & 60.18 & 64.26 & 68.07 & 70.04 & 70.79 & 67.39 \\
\hline $\mathrm{SEM}^{2}$ & & 0.70 & 0.36 & 0.44 & 0.39 & 0.33 & 0.32 \\
\hline$P$ value & & 0.839 & 0.714 & 0.198 & 0.309 & 0.308 & 0.565 \\
\hline
\end{tabular}

${ }^{1}$ PGRE: Korean ginseng root extract; ${ }^{2}$ Mean of standard error.

Means within a column with different superscripts differ significantly. $* P<0.05$; $* * P<0.01$.

consistent with Odabasi et al. (2007), who reported that a decrease in pigmentation was associated with a decrease in the amount of redness $\left(\mathrm{a}^{*}\right)$ in the eggshell. The same researchers claimed that the lighter the shell in colour, the less redness it contains, and this negative correlation becomes stronger as the hen ages over the first 10 months of the laying cycle. Hence, the lighter coloured eggshells (higher $\mathrm{L}^{*}$ ) would have less redness (a*). However, an additional measure representing $\mathrm{C}^{*}$ indicated similar trends for $\mathrm{b}^{*}$ and $\mathrm{C}^{*}$, which imply no advantage of this attribute in characterizing eggshell colour ( $\mathrm{Li}$ et al., 2006). $\mathrm{L}^{*}$ is the most similar in the colour index to total colour, $\Delta \mathrm{E}^{*}$ (Ingram et al., 2008).

The averages of the overall measurements at three points on the same egg were also very close to those of the one point measurement. The results indicated high uniformity of eggshell pigmentation. Förster \& Flock (1997) studied the eggshell colour in commercial brown egg strains of 52 to 60 weeks of age. They found the average range of $\mathrm{L}^{*}, \mathrm{a}^{*}$ and $\mathrm{b}^{*}$ values among all strains to be between 62.6 and 69.6; 13.3 and 
Table 6 Effects of dietary PGRE levels on means of internal egg quality characteristics

\begin{tabular}{|c|c|c|c|c|c|c|c|}
\hline \multirow{2}{*}{ Parameters } & \multirow{2}{*}{$\begin{array}{l}\text { PGRE }^{1} \\
(\mathrm{mg} / \mathrm{kg})\end{array}$} & \multicolumn{6}{|c|}{ Weeks } \\
\hline & & 3 & 5 & 7 & 9 & 11 & Overall \\
\hline \multirow{4}{*}{ Yolk colour } & 0 & 11.00 & $9.50^{\mathrm{b}}$ & $10.88^{\mathrm{ab}}$ & 10.57 & $11.63^{\mathrm{a}}$ & $10.67^{\mathrm{a}}$ \\
\hline & 50 & 7.00 & $10.63^{\mathrm{a}}$ & $11.25^{\mathrm{a}}$ & 10.62 & $10.88^{\mathrm{b}}$ & $10.62^{\mathrm{a}}$ \\
\hline & 100 & 6.50 & $8.86^{\mathrm{b}}$ & $10.25^{\mathrm{bc}}$ & 10.38 & $10.57^{b}$ & $9.81^{\mathrm{b}}$ \\
\hline & 150 & 6.75 & $8.75^{\mathrm{b}}$ & $9.63^{c}$ & 10.13 & $11.63^{\mathrm{a}}$ & $9.67^{\mathrm{b}}$ \\
\hline $\mathrm{SEM}^{2}$ & & 0.69 & 0.18 & 0.17 & 0.11 & 0.14 & 0.12 \\
\hline$P$ value & & 0.058 & $0.000^{* *}$ & $0.002 * *$ & 0.385 & $0.009^{* *}$ & $0.001 * *$ \\
\hline \multirow{4}{*}{ Albumen pH } & 0 & 8.54 & 8.59 & 8.62 & $8.72^{\mathrm{b}}$ & 8.66 & 8.64 \\
\hline & 50 & 8.59 & 8.52 & 8.65 & $8.94^{\mathrm{a}}$ & 8.78 & 8.72 \\
\hline & 100 & 8.64 & 8.53 & 8.70 & $8.78^{\mathrm{b}}$ & 8.63 & 8.66 \\
\hline & 150 & 8.63 & 8.59 & 8.56 & $8.69^{\mathrm{b}}$ & 8.73 & 8.64 \\
\hline $\mathrm{SEM}^{2}$ & & 0.02 & 0.03 & 0.03 & 0.02 & 0.02 & 0.01 \\
\hline$P$ value & & 0.592 & 0.697 & 0.350 & $0.000^{* *}$ & 0.135 & 0.173 \\
\hline \multirow{4}{*}{ Albumen index } & 0 & 14.43 & 13.46 & 13.35 & $10.89^{\mathrm{b}}$ & 10.84 & 12.31 \\
\hline & 50 & 15.34 & 13.14 & 13.18 & $15.25^{\mathrm{a}}$ & 11.70 & 13.44 \\
\hline & 100 & 13.71 & 14.58 & 14.10 & $11.40^{\mathrm{b}}$ & 11.54 & 12.94 \\
\hline & 150 & 14.28 & 14.90 & 13.87 & $12.42^{\mathrm{b}}$ & 11.49 & 13.29 \\
\hline SEM $^{2}$ & & 0.58 & 0.46 & 0.41 & 0.52 & 0.31 & 0.22 \\
\hline$P$ value & & 0.891 & 0.477 & 0.857 & $0.008^{* *}$ & 0.780 & 0.286 \\
\hline \multirow{4}{*}{ Yolk index } & 0 & 47.1 & 45.5 & 45.9 & 44.1 & 44.7 & 45.20 \\
\hline & 50 & 43.8 & 46.9 & 45.6 & 46.3 & 45.6 & 45.96 \\
\hline & 100 & 48.6 & 47.3 & 46.3 & 46.0 & 44.1 & 46.12 \\
\hline & 150 & 46.5 & 47.2 & 44.6 & 45.9 & 43.6 & 45.45 \\
\hline $\mathrm{SEM}^{2}$ & & 0.72 & 0.52 & 0.32 & 0.62 & 0.41 & 0.23 \\
\hline$P$ value & & 0.185 & 0.585 & 0.261 & 0.632 & 0.364 & 0.486 \\
\hline \multirow{4}{*}{ Shell weight } & 0 & 5.18 & 5.44 & 6.28 & $6.48^{\mathrm{a}}$ & 6.50 & 6.10 \\
\hline & 50 & 5.30 & 5.35 & 5.96 & $5.85^{\mathrm{b}}$ & 6.49 & 5.88 \\
\hline & 100 & 5.02 & 5.47 & 5.72 & $6.41^{\mathrm{a}}$ & 6.35 & 5.93 \\
\hline & 150 & 5.13 & 5.54 & 6.02 & $6.26^{\mathrm{ab}}$ & 6.45 & 5.96 \\
\hline $\mathrm{SEM}^{2}$ & & 0.07 & 0.10 & 0.09 & 0.08 & 0.06 & 0.05 \\
\hline$P$ value & & 0.732 & 0.933 & 0.166 & $0.022 *$ & 0.840 & 0.502 \\
\hline \multirow{4}{*}{ Haugh unit (score) } & 0 & 98.9 & 98.2 & 99.3 & 92.5 & 92.4 & 95.88 \\
\hline & 50 & 103.0 & 97.2 & 99.2 & 96.8 & 94.6 & 97.30 \\
\hline & 100 & 99.4 & 100.3 & 99.6 & 94.0 & 94.4 & 97.21 \\
\hline & 150 & 102.2 & 101.1 & 100.9 & 97.3 & 94.7 & 98.91 \\
\hline $\mathrm{SEM}^{2}$ & & 1.06 & 1.10 & 1.07 & 0.79 & 0.94 & 0.51 \\
\hline$P$ value & & 0.549 & 0.571 & 0.947 & 0.100 & 0.800 & 0.205 \\
\hline
\end{tabular}

${ }^{1}$ PGRE: Korean ginseng root extract; ${ }^{2}$ Mean of standard error.

Means within a column with different superscripts differ significantly. ${ }^{*} P<0.05$; ${ }^{* *} P<0.01$. 
Table 7 Change in colour of eggshell lightness $\left(\mathrm{L}^{*}\right)$, redness $\left(\mathrm{a}^{*}\right)$, yellowness $\left.\left(\mathrm{b}^{*}\right)\right]^{1}$ during 12 -week laying period

\begin{tabular}{|c|c|c|c|c|c|c|c|}
\hline \multirow{2}{*}{ Parameters } & \multirow{2}{*}{$\begin{array}{l}\text { PGRE }^{2} \\
(\mathrm{mg} / \mathrm{kg})\end{array}$} & \multicolumn{6}{|c|}{ Weeks } \\
\hline & & 3 & 5 & 7 & 9 & 11 & Overall \\
\hline \multirow{4}{*}{$\mathrm{L}^{*}$} & 0 & $65.6^{\mathrm{b}}$ & 68.9 & 64.6 & 63.6 & $62.8^{\mathrm{b}}$ & 65.0 \\
\hline & 50 & $67.1^{\mathrm{b}}$ & 68.7 & 66.8 & 66.2 & $63.6^{\mathrm{b}}$ & 66.4 \\
\hline & 100 & $71.7^{\mathrm{a}}$ & 67.9 & 63.5 & 63.8 & $67.8^{\mathrm{a}}$ & 66.3 \\
\hline & 150 & $67.2^{\mathrm{b}}$ & 66.0 & 63.8 & 65.8 & $64.0^{\mathrm{b}}$ & 65.1 \\
\hline $\mathrm{SEM}^{3}$ & & 0.75 & 0.63 & 0.54 & 0.58 & 0.62 & 0.30 \\
\hline$P$ value & & $0.008^{* *}$ & 0.349 & 0.121 & 0.286 & $0.014^{*}$ & 0.235 \\
\hline \multirow{4}{*}{$a^{*}$} & 0 & $13.86^{\mathrm{a}}$ & 11.20 & 14.68 & 15.20 & $14.45^{\mathrm{a}}$ & 13.88 \\
\hline & 50 & $12.50^{\mathrm{ab}}$ & 11.29 & 14.55 & 14.14 & $13.88^{\mathrm{a}}$ & 13.38 \\
\hline & 100 & $10.80^{\mathrm{b}}$ & 11.64 & 15.76 & 15.68 & $11.59^{\mathrm{b}}$ & 13.42 \\
\hline & 150 & $12.78^{\mathrm{ab}}$ & 12.98 & 15.65 & 14.30 & $13.94^{\mathrm{a}}$ & 14.06 \\
\hline \multirow{6}{*}{$\begin{array}{c}\text { SEM }^{3} \\
P \text { value }\end{array}$} & & 0.40 & 0.38 & 0.33 & 0.38 & 0.37 & 0.20 \\
\hline & & $0.043^{*}$ & 0.320 & 0.446 & 0.437 & $0.020 *$ & 0.559 \\
\hline & 0 & $24.23^{b}$ & 22.93 & 24.84 & 27.78 & 24.70 & 24.99 \\
\hline & 50 & $29.99^{\mathrm{a}}$ & 25.18 & 26.70 & 29.29 & 24.76 & 26.78 \\
\hline & 100 & $25.41^{\mathrm{b}}$ & 24.63 & 25.87 & 27.35 & 25.53 & 25.81 \\
\hline & 150 & $25.16^{\mathrm{b}}$ & 27.47 & 26.43 & 27.53 & 23.82 & 26.19 \\
\hline $\mathrm{SEM}^{3}$ & & 0.72 & 0.72 & 0.57 & 0.64 & 0.56 & 0.31 \\
\hline$P$ value & & $0.005^{* *}$ & 0.169 & 0.693 & 0.718 & 0.774 & 0.216 \\
\hline \multirow{4}{*}{ Hue } & 0 & $1.05^{\mathrm{b}}$ & 1.11 & 1.04 & 1.07 & $1.04^{\mathrm{b}}$ & 1.06 \\
\hline & 50 & $1.18^{\mathrm{a}}$ & 1.14 & 1.07 & 1.12 & $1.06^{\mathrm{b}}$ & 1.11 \\
\hline & 100 & $1.17^{\mathrm{a}}$ & 1.13 & 1.02 & 1.05 & $1.15^{\mathrm{a}}$ & 1.09 \\
\hline & 150 & $1.10^{\mathrm{ab}}$ & 1.13 & 1.04 & 1.09 & $1.04^{\mathrm{b}}$ & 1.08 \\
\hline $\mathrm{SEM}^{3}$ & & 0.018 & 0.01 & 0.01 & 0.01 & 0.012 & 0.01 \\
\hline$P$ value & & $0.028 *$ & 0.841 & 0.450 & 0.066 & $0.002^{* *}$ & 0.080 \\
\hline \multirow{4}{*}{ Chroma } & 0 & $27.93^{\mathrm{b}}$ & 25.58 & 28.87 & 31.68 & 28.64 & 28.63 \\
\hline & 50 & $32.49^{\mathrm{a}}$ & 27.67 & 30.46 & 32.58 & 28.45 & 30.02 \\
\hline & 100 & $27.61^{\mathrm{b}}$ & 27.27 & 30.34 & 31.56 & 28.07 & 29.17 \\
\hline & 150 & $28.28^{\mathrm{b}}$ & 30.43 & 30.79 & 31.07 & 27.64 & 29.79 \\
\hline $\mathrm{SEM}^{3}$ & & 0.64 & 0.75 & 0.57 & 0.67 & 0.57 & 0.32 \\
\hline$P$ value & & $0.005^{* *}$ & 0.145 & 0.670 & 0.896 & 0.938 & 0.418 \\
\hline \multirow{4}{*}{$\Delta \mathrm{E}^{*}$} & 0 & $71.3^{\mathrm{c}}$ & 73.6 & 70.8 & $71.1^{\mathrm{C}}$ & $69.1^{\mathrm{b}}$ & $71.2^{\mathrm{b}}$ \\
\hline & 50 & $74.6^{\mathrm{ab}}$ & 74.2 & 73.4 & $73.9^{\mathrm{a}}$ & $69.8^{\mathrm{b}}$ & $73.0^{\mathrm{a}}$ \\
\hline & 100 & $76.8^{\mathrm{a}}$ & 73.4 & 70.5 & $71.4^{\mathrm{c}}$ & $73.5^{\mathrm{a}}$ & $72.6^{\mathrm{a}}$ \\
\hline & 150 & $72.9^{\mathrm{bc}}$ & 72.7 & 70.9 & $72.9^{\mathrm{b}}$ & $69.8^{\mathrm{b}}$ & $71.7^{\mathrm{ab}}$ \\
\hline $\mathrm{SEM}^{3}$ & & 0.69 & 0.45 & 0.48 & 0.39 & 0.47 & 0.23 \\
\hline$P$ value & & $0.009 * *$ & 0.750 & 0.103 & $0.025^{*}$ & $0.001^{* *}$ & $0.021^{*}$ \\
\hline
\end{tabular}


17.6; 24.4 and 27.8, respectively. Li et al. (2006) determined the average $\mathrm{L}^{*}$, a* and $\mathrm{b}^{*}$ values of brown eggshell from 31 weeks old hens to be between 61.1 and 66.9, 16.6 and 20.6, 23.9 and 26.9 for brown eggs, respectively. In the present study, the same parameter values were $65.02 \sim 66.37 ; 13.38 \sim 14.06$ and $24.99 \sim$ 26.78, respectively for Atak-S brown egg. This is consistent with previous results, with minor age effects. Shell colour is usually affected by genetic background, the season of lay, nutrition, diseases, all kinds of stimulus, drug, etc. (Wei et al., 1992, Yang et al., 2009).

Serum blood parameters of laying hens at 32 weeks of age are summarized in Table 8 . There were no significant differences among treatments in terms of the serum glucose, cholesterol and triglyceride concentrations. However, serum cholesterol was numerically lower in PGRE groups than in the control. This agrees with Ao et al. (2011), who indicated that serum cholesterol concentrations varied from $176 \mathrm{mg} / \mathrm{dL}$ to $185 \mathrm{mg} / \mathrm{dL}$ and there were no significant differences when different levels of fermented red ginseng extract were supplemented. Several studies observed that the addition of dietary ginseng decreased the level of blood lipids (Muwalla \& Abuirmeileh, 1990; Yokozawa et al., 2004). Jang et al. (2007) demonstrated that total cholesterol concentration was decreased by fermented ginseng culture in laying hens. However, this effect was not confirmed in the present study, probably because of too low a level of supplementation.

Table 8 Effect of PGRE supplementation on some serum traits in laying hens at end of experiment

\begin{tabular}{|c|c|c|c|c|c|c|}
\hline \multirow[b]{2}{*}{ Parameters } & \multicolumn{4}{|c|}{$\mathrm{PGRE}^{1}$ in diet (mg/kg) } & \multirow[b]{2}{*}{$\mathrm{SEM}^{2}$} & \multirow[b]{2}{*}{$P$ Value } \\
\hline & 0 & 50 & 100 & 150 & & \\
\hline Glucose (mg/dL) & 307 & 293 & 303 & 304 & 3.39 & 0.549 \\
\hline Cholesterol (mg/dL) & 160 & 143 & 145 & 148 & 11.76 & 0.860 \\
\hline Triglyceride (mg/dL) & 1414 & 1272 & 1141 & 1449 & 130.8 & 0.852 \\
\hline
\end{tabular}

${ }^{1}$ PGRE: Korean ginseng root extract; ${ }^{2}$ Mean of standard error; $P>0.05$.

\section{Conclusion}

The results of this study showed that overall, dietary supplementation of PGRE to laying hens' diet had no adverse effects on productivity performance, health status of the hens, external and internal egg quality, eggshell colour and some serum biochemical measurements. Further research is needed to determine the potential of supplementing PRGE to hens' diets to improve the welfare of laying hens in different management conditions, including various stress factors such as environmental and physiological stresses, dietary ingredients and nutrient content.

\section{Acknowledgements}

The authors are thankful to the staff in the Department of Animal Science, Faculty of Agriculture, University of Gaziosmanpaşa, Tokat, Turkey.

\section{References}

Ao, X., Zhou, T.X., Kim, H.J., Hong, S.M. \& Kim, I.H., 2011. Influence of fermented Red Ginseng extract on broilers and laying hens. Asian-Aust. J. Anim. Sci. 24, 993-1000.

Attele, A.S., Wu, J.A. \& Yuan, C.S., 1999. Ginseng pharmacology: multiple constituents and multiple actions. Biochem. Pharmacol. 58, 1685-1693.

Brugalli, I., 2003. Alimentação alternativa: a utilização de fitoterápicos ou nutracêuticos como moduladores da imunidade e desempenho animal. In: Simpósio Sobre Manejo E Nutrição De Aves E Suínos, Campinas. Anais Campinas: Colégio Brasileiro de Nutrição Animal. pp. 167-182. (in Portuguese).

Choi, K.T., 2008. Botanical characteristics pharmacological effects and medicinal components of Korean Panax ginseng C.A. Meyer. Acta Pharmacol. Sin. 29, 1109-1118.

Chukwuka, O.K., Okoli, I.C., Okeudo, N.J., Udedibie, A.B.I., Ogbuewu, I.P., Aladi, N.O., Iheshiulor, O.O.M. \& Omede, A.A., 2011. Egg quality defects in poultry management and food safety. Asian J. 
Agric. Res. 5, 1-16.

Colin, G.S., George, B. \& Ensminger, M.E., 2004. Poultry Science. 4th rev. ed. Pearson Prentice Hall, Upper Saddle River, N.J., USA.

Doyon, G., Bernier-Cardou, M., Hamilton, R.M.G., Castalgne, F. \& Randall, C.J., 1986. Egg quality 2. Albumen quality of eggs from five commercial strains of white leghorn hens during one year of lay. Poult. Sci. 65, 63-66.

DSM, 2013. Yolk color fan. Available at www.dsmnutritionalproducts.com (accessed: 10 February 2013).

Faixova, Z. \& Faix, S., 2008. Biological effects of rosemary essential oil (Review). Folia Veterinaria 52, 135-139.

Fascina, V.B., Sartori, J.R., Gonzales, E., de Carvalho, F.B., Pereira de Souza, I.M.G., Polycarpo, G.V., Stradiotti, A.C. \& Pelícia, V.C., 2012. Phytogenic additives and organic acids in broiler chicken diets. R. Bras. Zootec. 41, 2189-2197.

Förster, A. \& Flock, D.K., 1997. Scope for further improvement of shell color in brown-egg type layers. Lohmann Information 20, 19-22.

Hamilton, R.M.G., 1982. Methods and factors that affect the measurement of egg shell quality. Poult. Sci. 61, 2022-2039.

Harms, R.H., Rossi, A.F., Sloan, D.R., Miles, R.D. \& Christmas, R.B., 1990. A method for estimating shell weight and correcting specific gravity for egg weight in eggshell quality studies. Poult. Sci. 69, 48-52.

Hu, C. \& Kitts, D.D., 2001. Free radical scavenging capacity as related to antioxidant activity and ginsenoside composition of Asian and North American ginseng extracts. JAOCS. 78, 249-255.

Ingram, D.R., Hatten, L.F. \& Homan, K.D., 2008. A Study on the relationship between eggshell color and eggshell quality in commercial broiler breeders. Int. J. Poult. Sci. 7, 700-703.

Jang, H.D., Kim, H.J., Cho, J.H., Chen, Y.J., Yoo, J.S., Min, B.J., Park, J.C. \& Kim, I.H., 2007. Effect of dietary supplementation of fermented wild ginseng culture by products on egg productivity, egg quality, blood characteristics and ginsenoside concentration of yolk in laying hens. Kor. J. Anim. Sci. 34, 271-278.

Jin, Y.H., Lee, K.T., Lee, W.I. \& Han, Y.K., 2011. Effects of storage temperature and time on the quality of eggs from laying hens at peak production. Asian-Aust. J. Anim. Sci. 24, 279-284.

Kamel, C., 2000. A novel look at a classic approach of plant extracts. Feed Mix-The International Journal of Feed, Nutrition and Technology 18, 19-24.

Kang, S.Y., Kim, S.H., Schini, V.B. \& Kim, N.D., 1995. Dietary ginsenosides improve endothelium dependent relaxation in the thoracic aorta of hypercholesterolemic rabbit. Gen. Pharmacol. 26, 483-487.

Kim, H.G., Yoo, S.R., Park, H.J., Lee, N.H., Shin, J.W., Sathyanath, R., Cho, J.H. \& Son, C.G., 2011. Antioxidant effects of Panax ginseng C.A. Meyer in healthy subjects: A randomized, placebocontrolled clinical trial. Food Chem. Toxicol. 49, 2229-2235.

Kim, H.Y., Kang, K.S., Yamabe, N. \& Yokozawa, T., 2008. Comparison of the effects of Korean ginseng and heat-processed Korean ginseng on diabetic oxidative stress. Am. J. Chin. Med. 36, 989-1004.

Ledvinka, Z., Skřrivan, M., Tůmová, E. \& Dlouhá, G., 2002. The effect the age and hens oviposition time on quality of eggs for hatching. In: Proc. Conf. Sustainable Development of Crop and Animal Production. Way of Development of Czech Countryside. September 25-26, 110, Prague.

Leeson, S. \& Summers, J.D., 1997. Commercial Poultry Nutrition. Second Edition. Available from: University Books, P.O. Box 1326, Guelph, Ontario, Canada, N1H 6N8.

Li, X.Y., Xu, G.Y., Hou, Z.C., Zhao, R. \& Yang, N., 2006. Variation of eggshell colour in different egg-type chickens. Arch. Geflügelkd. 70, 278-282.

Lim, H.S., Namkung, H. \& Paik, I.K., 2003. Effects of phytase supplementation on the performance, egg quality, and phosphorous excretion of laying hens fed different levels of dietary calcium and nonphytate phosphorous. Poult. Sci. 82, 92-99.

Lim, S., Yoon, J.W., Choi, S.H., Cho, B.J., Kim, J.T., Chang, H.S., Park, H.S., Park, K.S., Lee, H.K., Kim, Y.B. \& Jang, H.C., 2009. Effect of ginsam, a vinegar extract from Panax ginseng, on body weight and glucose homeostasis in an obese insulin-resistant rat model. Metabolism 58, 8-15.

Lokaewmanee, K., Yamauchi, K., Komori, T. \& Saito, K., 2011. Enhancement of yolk color in raw and boiled egg yolk with lutein from marigold flower meal and marigold flower extract. J. Poult. Sci. 48, 25-32. 
Lu, J.M., Yao, Q. \& Chen, C., 2009. Ginseng compounds: an update on their molecular mechanisms and medical applications. Curr. Vasc. Pharmacol. 7, 293-302.

Muwalla, M.M. \& Abuirmeileh, N.M., 1990. Suppression of avian hepatic cholesterogenesis by dietary ginseng. J. Nutr. Biochem. 1, 518-521.

Nordstrom, J.D. \& Ousterhout, I.E., 1982. Estimation of shell weight and thickness from egg specific gravity and egg weight. Poult. Sci. 61, 1991-1995.

North, M.O., 1984. Breeder Management. In Commercial Chicken Production Manual. The Avi. Publishing Company. Inc. Westport, Connecticut, 240-321.

NRC, 1994. Nutrient Requirements of Poultry. 9th rev. ed. Natl. Acad. Press, Washington, D.C., USA.

Odabasi, A.Z., Miles, R.D., Balaban, M.O. \& Portier, K.M., 2007. Changes in brown eggshell color as the hen ages. Poult. Sci. 86, 356-363.

Oh, C.H., Kim, G.N., Lee, S.H., Lee, J.S. \& Jang, H.D., 2010. Effects of heat processing time on total phenolic content and antioxidant capacity of ginseng Jung Kwa. J. Ginseng Res. 34, 198-204.

Olobatoke, R.Y. \& Mulugeta, S.D., 2011. Effect of dietary garlic powder on layer performance, fecal bacterial load, and egg quality. Poult. Sci. 90, 665-670.

Oyaizu, M., 1986. Studies on product of browning reaction prepared from glucose amine. Jpn. J. Nutr. 44, 307-315.

Palazon, J., Cusido, R.M., Bonfil, M., Mallol, A., Moyamo, E., Marales, C. \& Pinol, M.T., 2003. Elicitation of different Panax ginseng transformed root phenotypes for an improvement ginsenoside production. Plant Physiol. Biochem. 41, 1019-1025.

Petrolli, T.G., Albino, L.F.T., Rostagno, H.S., Gomes, P.C., Tavernari, F.D.C. \& Balbino, E.M., 2012. Herbal extracts in diets for broilers. R. Bras. Zootec. 41, 1683-1690.

Re, R., Pellegrini, N., Proteggente, A., Pannala, A., Yang, M., Rice-Evans, C.A., 1999. Antioxidant activity applying an improved ABTS radical cation decolorization assay. Free Radical Bio. Med. 26, 1231-1237.

Roush, W.B.T., 1981. 159 calculator program for Haugh unit calculation. Poult. Sci. 60, 1086-1088.

Saumya, S.M. \& Mahaboob Basha, P., 2011. In vitro evaluation of free radical scavenging activities of Panax ginseng and Lagerstroemia Speciosa: A comparative analysis. Int. J. Pharm. Pharm. Sci. 3, 165169.

Sekeroğlu, A., Sarica, M., Demir, E., Ulutas, Z., Tilki, M., Saatci, M. \& Omed, H., 2010. Effects of different housing systems on some performance traits and egg qualities of laying hens. J. Anim. Vet. Adv. 9, 1739-1744.

Shim, J.Y., Kim, M.H., Kim, H.D., Ahn, J.Y., Yun, Y.S. \& Song, J.Y., 2010. Protective action of the immunomodulator ginsan against carbon tetrachloride-induced liver injury via control of oxidative stress and the inflammatory response. Toxicol. Appl. Pharmacol. 242, 318-325.

Silversides, F.G. \& Villeneuve, P., 1994. Is the Haugh unit correction for egg weight valid for eggs stored at room temperature? Poult. Sci. 73, 50-55.

Slinkard, K. \& Singleton, V.L., 1977. Total phenol analyses: automation and comparison with manual methods. Am. J. Enol. Viticult. 28, 49-55.

Spelman, K., Burns, J., Nichols, D., Winters, N., Ottersberg, S. \& Tenborg, M., 2006. Modulation of cytokine expression by traditional medicines: a review of herbal immunomodulators. Altern. Med. Rev. 11, 128-150.

SPSS, 2010. Statistical Package in Social Sciences for Windows. Statistical Innovations Inc., Chicago, USA.

Sticher, O., 1998. Getting to the root of ginseng. Chemtech. 28, 26-32.

Takahashi, M., Tokuyama, S. \& Kaneto, H., 1992. Anti-stress effect of ginseng on the inhibition of the development of morphine tolerance in stressed mice. Jpn. J. Pharmacol. 59, 399-404.

Tůmová, E. \& Ebeid, T., 2005. Effect of time of oviposition on egg quality characteristics in cages and in a litter housing system. Czech J. Anim. Sci. 50, 129-134.

Tůmová, E., Zita, L., Hubený, M., Skřivan, M. \& Ledvinka, Z., 2007. The effect of oviposition time and genotype on egg quality characteristics in egg type hens. Czech J. Anim. Sci. 52, 26-30.

Um, J.S. \& Paik, I.K., 1999. Effects of microbial phytase supplementation on egg production, eggshell quality, and mineral retention of laying hens fed different levels of phosphorus. Poult. Sci. 78, 75-79.

Wei, R., Bitgood, J.J. \& Dentine, M.R., 1992. Inheritance of tinted eggshell colours in white-shell stocks. Poult. Sci. 71, 406-418. 
Wu, J. \& Zhong, J.J., 1999. Production of ginseng and its bioactive components in plant cell culture: Current technological and applied aspects. J. Biotechnol. 68, 89-99.

Yang, H.M., Wang, Z.Y. \& Lu, J., 2009. Study on the relationship between eggshell colors and egg quality as well as shell ultrastructure in Yangzhou chicken. Afr. J. Biotechnol. 8, 2898-2902.

Yıldırım, A. \& Erener, G., 2010. The possibilities using of Ginseng (Panax spp.) in poultry nutrition. Hasad J. Anim. Sci. 26, 56-59 (in Turkish).

Yokozawa, T., Satoh, A. \& Cho, E.J., 2004. Ginsenoside-Rd attenuates oxidative damage related to aging in senescence-accelerated mice. J. Pharm. Pharmacol. 56, 107-113.

Zhang, Q.H., Wu, C.F., Duan, L. \& Yang, J.Y., 2008. Protective effects of total saponins from stem and leaf of Panax ginseng against cyclophosphamide-induced genotoxicity and apoptosis in mouse bone marrow cells and peripheral lymphocyte cells. Food Chem. Toxicol. 46, 293-302. 